\title{
The Turkish Version Of The Epic "Oshik Najab" About The Artistic Features
}

\author{
S.Jepbarova \\ Berdak Karakalpak State University
}

\begin{abstract}
This article compares the artistic features of the popular epic "Oshik Najab" with the Uzbek, Turkmen and Karakalpak versions. Typological similarities in them are revealed.
\end{abstract}

Keywords:

Epic, metaphor, analogy, image, poem, prose

Article Received: 18 October 2020, Revised: 3 November 2020, Accepted: 24 December 2020

We all know that from ancient times our people glorified music and music, and tried to describe their inner feelings and living conditions. In particular, this tradition has been widely preserved in our folklore. One of the anonymous folk tales "Oshik Najab", which embodies the passion of our people for the art of music, is widely spread among the Turkic peoples, including the Uzbek, Turkmen and Karakalpak peoples. This story mainly describes the art of generosity, the power of music, the people's high respect for the art of generosity, love, heroism, patience, humility, humanity. In addition, the teacher recognizes the role of the student and the role of the arts.

The plot of the story is inextricably linked with the events of the story "Oshik Najab" and "Oshik Alband". Therefore, the story "Oshiq Najab" can be considered as a continuation of the story "Oshiq Alband". In other words, in the story "Lover Alban" the events are described through the image of the Albanian mystery of the art of divination, the power of the song and its importance in human life, human virtues, patience, cults, etc. described in detail. In the story "Lover Najab" he meets the next destiny of the Albanian branch, Najab, and his mother Sona, the marriage of the Albanian branch are described.
Along with prose, poetry is also widely used in the story to describe events related to the art of music and charity. For this reason, S. Gutlieva, who studied the Turkmen epic "Oshik Najab", emphasizes that poetry occupies a special place in the main part of the plot. Indeed, poetry plays a great poetic role in revealing the spiritual inner experiences, feelings and character of the heroes. For this reason, one of the main features of the work is the use of more poetic lines in the story than ordinary black words. Poetic lines are widely used in the epic, firstly, to express the attitude of the protagonists to the events, and secondly, to express the events in an effective, emotional way. Commenting on the musical world of the story, researcher G. Yazmammedova divides the songs in the story into two large groups. For example, the artistic clarity of the content of the images divides the world of music in the epic "Oshik Najab" into two main groups: the musical drama of the first part, which contains 10 songs, is divided into 2 groups. The first four songs belong to the first group and are named after Albandi, who set out in search of the place he saw in his dream. The trio of songs are associated with the portrait of Sona in the epic, which is: "I will not forget the name of Sona", "Begr of Tabriz, is Sonam here?", "Sona gelin" has character. 
The second group consists of 6 songs, which include events related to Najab. The second group can be conditionally divided into three types, which are not large. They show that the character of the protagonist is formed in different places, and Najab is formed as a creator" .

The songs of the heroes and characters in the story are a clear proof of this. For example, in the story, Najab addresses Abadan, who fell in love with him through songs such as "Who's next?", "Show me a maple tree", "Nozli kelin".

The story also reveals dramatic characters in the narrations of Alban and Najab. Indicates cases of escalation of conflicts.

In the second half of the story "Oshik Najab" there is a contradiction in the resolution of events. For example, Najab's encounter with Munayim Khan reveals the beginning of another episode in the story. That is, along with these events, we see in the story the creation of another hero - the image of Munayim. It mainly describes the love character of the heroes in such songs as "Mylayim khan gelsin diydi", "Kemal yarym", "Ozun uchin al gach meni", "Yar meni", "Toya geldinmi?", "Gurban bolayn", "Gurbana geldim". That is why in the second part of the story there are more contradictions than in the first half. The widespread use of songs in the story is due, firstly, to the specific programs of the story, and secondly, to the fact that the feelings of lovers are very close to each other.

One of the main features of the story is the combination of epic, lyrical and heroic, human qualities. From this point of view, the image of the heroes of the story is divided into two types: positive and negative. In the story, we see that the characters are often revealed through songs. Commenting on the issues of the artistic service of songs in the story, S. Gutlieva also notes that the task of revealing the spirituality, inner experiences and feelings of the protagonists in the story, especially through poetry, is realized. "Epic songs are inextricably linked with the growth of the plot. It is the main tool in the effective expression of every detail, episode, event in revealing the inner world, thoughts, feelings, characters, relationships of the heroes. It contains 23 songs with a total of 128 stanzas, of which sixty-three consist of 8 syllables and sixty-five of 11 syllables. Doston's songs are composed in a syllabic weight typical of Turkish poetry.

The widespread use of these forms of song in the epic is characteristic of music. For example, in the Turkmen version:

Your voice is juniper // continued, a

The gentle khan said // let him come. b

You were asked // followed, a

The gentle khan said // let him come. B

The lines of this song have 8 syllables and are rhymed in the form $a b$ a b. Rows 2 and 4 of the song are in the form of a satellite.

Gulchaman's songs, which conveyed Munayimkhan's greetings to Najab, are also quoted in the Uzbek version. For example:

Your voice continued,

He said, "Let him come."

They asked you, they searched for you,

He said that he should come.

The songs in the epic have 11 syllables. For example, in the story it is possible to sing the singing songs of Alband and Najab. In the Uzbek version:

Alban:

Greetings to the people,

Adam Safiullo did not leave the city.

Where did they stand and play,

They have been used for many years. Najab:

The world is in the middle of nowhere,

The man was beaten to death.

Before, there was no city,

At first they left the city of $\mathrm{Kufa}^{2}$

The song consists of 11 syllables. Metaphors are also widely used in the song, saying that the world is narrow - "square". Otherwise, let's pay attention to the lines of the song that Najab sang to the bride.

In Iran, in Turan, among the people of Ajam, I have never seen such a beautiful young woman, Among the good, in the flower of paradise, 
I have never seen such a beautiful young woman as you ${ }^{1}$.

This song has 11 syllables and is rhymed in the form $a b a b$. The parables are widely used in the song to describe the portrait of a beautiful bride, comparing her with "among the good, in the flower of paradise," and to say, "I have never seen such a beautiful young woman as you." Or:

Your neck is long, your cheeks are long,

Your lips are sugary, your cheeks are swollen,

I have big eyes to see your flower face,

Look, your face is younger than a straw.

In the lines of the song, he describes the girl as tall, with red lips, and likens her to a "light". He compares the length of his hair to that of a "dutora." Here, the "net of the duo" as an artistic detail fulfills the inner feelings of the protagonist to the girl, the artistic task of drawing a portrait of her.

In this poem, Munayimhon, who is in love with Najab in Dostabad, can also be seen to have a broad sense of allegorical and internal thought. For example:

My wandering in the desert,

My face in the water,

Listen, my uncles,

I came to the victim.

I am the morning star of your city,

I am the daughter of your great vizier,

My dear khan,

The victim arrived.

Here the metaphors "ahu - deer, mahy fish" are used in an allegorical sense to express Munayim Khan's love for Najab, his feelings for him, his inner feelings. He likens himself to a star, saying, "I am the morning star of your city." The tropes used here, in turn, serve to enhance the artistry and emotionality of the story.

In conclusion, it is worth noting that the story "Oshiq Najab" has a wide place in the hearts of readers due to its artistic nature.

\section{REFERENCES}

[1] 1.Gutliyeva S. The story of "Nejep oglan". -Charzhev. 1990
[2] Epics of Khorezm. Love letter. Prepared by: SR Ruzimbaev, SS Ruzimbaev. Khorezm, 2009.

[3] Yazmammadova G. The musical world of the poem "Nejep oglan". Turkmenistan newspaper. June 27, 2020,

[4] Gaylieva Ogulbay Kurbanmuratovna About the composite features of the trilateral art forms in modern Uzbek, Turkmen and Karakalpak poetry. Anglisticum Journal (IJLLIS), Volume: 7 | Issue: 9. Page 2018.| 27-33. https://doi.org/10.5281/zenodo.1451822 